Proc. Estonian Acad. Sci. Geol., 2004, 53, 4, 246-256

\title{
Apatite varieties in the shell of the Cambrian lingulate brachiopod Obolus apollinis Eichwald
}

\author{
Jüri Nemliher $^{\mathrm{a}}$, Tiia Kurvits ${ }^{\mathrm{b}}$, Toivo Kallaste ${ }^{\mathrm{a}}$, and Ivar Puura ${ }^{\mathrm{b}}$ \\ a Institute of Geology at Tallinn University of Technology, Estonia pst. 7, 10143 Tallinn, Estonia; \\ nemliher@gi.ee \\ b Institute of Geology, University of Tartu, Vanemuise 46, 51014 Tartu, Estonia; Tiia.Kurvits@ut.ee, \\ Ivar.Puura@ut.ee.
}

Received 5 July 2004, in revised form 13 September 2004

\begin{abstract}
An XRD study of heat-treated shell samples of the lingulate brachiopod Obolus apollinis Eichwald from the upper Cambrian (Furongian) of NW Russia (basal Tosna Formation, Lava River section) revealed the presence of two phases of apatite persisting the temperatures from 200 to $700{ }^{\circ} \mathrm{C}$. At higher temperatures, 900 and $1000{ }^{\circ} \mathrm{C}$, only one phase was detected. The lattice parameters of the two phases suggest possible preservation of carbonate-hydroxylapatite within the compact laminae of initially organo-phosphatic lingulate shells. The formation of another phase, carbonate-fluorapatite, is attributed to the precipitation of apatite to the free space available after disintegration of organic tissues of the shell and to partial recrystallization of initial shell apatite.
\end{abstract}

Key words: brachiopods, XRD, apatite, taphonomy, Cambrian, NW Russia.

\section{INTRODUCTION}

Lingulate brachiopods represent a class of marine invertebrates (Lingulata Gorjansky \& Popov) existing from the Lower Cambrian to the present (Holmer \& Popov 2000). Lingulates are the only Recent invertebrates known to build their exoskeleton of apatite. The long range of stratigraphic distribution, abundance in the early Palaeozoic, and the presence of modern representatives make lingulate brachiopods intriguing model objects for the studies of skeletal mineralogy.

Our previous XRD studies of fossil lingulates from 14 Cambrian-Ordovician localities in Estonia and NW Russia showed significant differences in average apatite lattice parameter values between shells from different genera and localities (Nemliher \& Puura 1996a). In further research, we observed slight differences in 
apatite lattice parameters in the shells from a local population of Recent Lingula anatina (Lamarck) (Puura \& Nemliher 2001) and that the lattice parameter $a$ in subfossil Discinisca tenuis (Sowerby) was slightly lower than that of the Recent shells (Nemliher \& Kallaste 2002). This led us to a hypothesis that at least part of the variation in shell mineralogy can be explained with the post-mortem incorporation of precipitated apatite into shells. Our new task is to use mineralogical parameters for distinguishing between different apatite phases within a single shell.

The above studies suggest that fossil lingulate shells may contain a wide range of apatite varieties precipitated in different conditions. However, an intriguing task is to find out, whether any $\mathrm{OH}$-containing carbonate fluorapatite variety characteristic of the Recent lingulate shells is preserved. This would allow us to evaluate the possibility of post-mortem preservation of apatite phases in the fossil shells even as old as 500 million years. In this study, we used XRD analysis of heat-treated fossil brachiopods to test the presence of $\mathrm{OH}$-containing carbonate fluorapatite in the shells of the Cambrian lingulate brachiopod Obolus apollinis Eichwald.

In search of the best-preserved fossils of the Cambrian ancestors of modern lingulates, the sandstones and unconsolidated sands of the Cambrian-Ordovician boundary beds of Estonia and NW Russia are of great interest. They yield lingulate brachiopod coquinas that have been used as commercial phosphorite deposits (Raudsep 1997). Since the early studies by Öpik (1929) these deposits have been called "Obolenphosphorite", or Obolus phosphorite.

Obolus apollinis Eichwald, 1829 is the type species of the genus Obolus, the type genus of the family Obolidae, which is one of the most diverse early Palaeozoic linguloid families (Popov \& Holmer 2003). Obolus apollinis appears in he uppermost Cambrian (Cordylodus proavus Biozone) and occurs in abundance in the Cambrian-Ordovician boundary beds of NW Russia, forming the Obolus phosphorite deposits commercially mined near Kingisepp (Krasilnikova \& Ilyin 1989). In Estonia, this species has a restricted distribution, occurring in some core sections near Rakvere and in Hiiumaa and in some outcrops in NE Estonia. The abundant species forming phosphorite deposits in Estonia are Ungula ingrica (Eichwald) and Schmidtites celatus (Volborth) (Popov et al. 1989; Nemliher \& Puura 1996a; Puura 1996).

\section{MATERIAL AND METHODS}

The studied sample of Obolus apollinis originates from the locality on the right bank of the Lava River in the Leningrad district, where the rocks from the Upper Cambrian Ladoga Formation to the Middle Ordovician Kunda Stage are exposed (Fig. 1). Here, the $3.55 \mathrm{~m}$ thick Tosna Formation overlies the upper Cambrian (Furongian) Ladoga Formation, with Westergaardodina bicuspidata, and is covered by the $0.8 \mathrm{~m}$ thick Koporye Formation, with Cordylodus angulatus appearing at its base (Popov et al. 1989; Puura 1996). The interval of the studied 


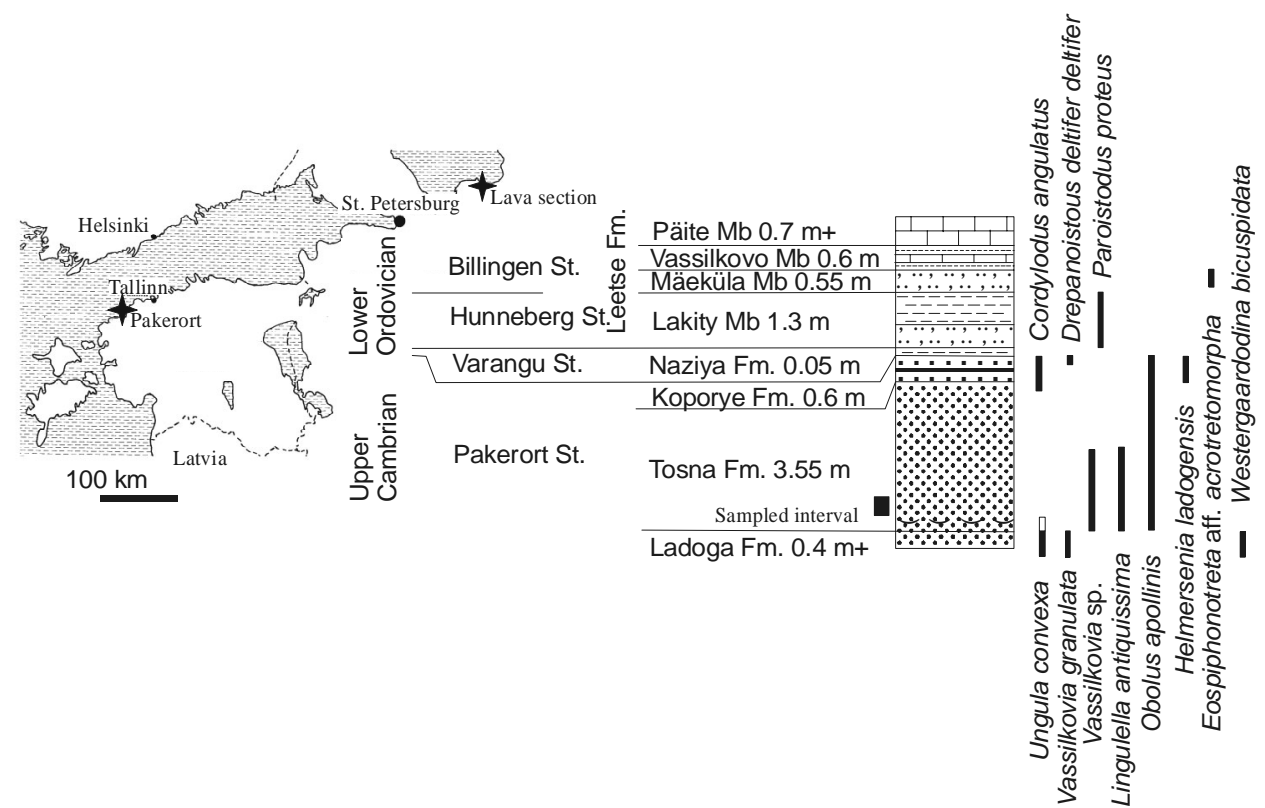

Fig. 1. Location of the studied and discussed outcrops and the stratigraphic position of the studied sample in the Lava River section.

sample is $60-70 \mathrm{~cm}$ above the base of the Tosna Formation (Fig. 1). No conodonts are known from the Tosna Formation and thus, according to the correlation with the global Cambrian-Ordovician boundary, this interval should be referred to as the uppermost Cambrian (Puura \& Viira 1999). Collection number 231, housed at the Institute of Geology at Tallinn University of Technology, contains Obolus apollinis Eichwald from the same locality and approximate level (Tosna Formation), including the specimens figured as $\mathrm{Br} 1703-\mathrm{Br} 1706$ by Popov et al. (1989).

The valves of Obolus apollinis Eichwald were picked out of the rock sample and cleaned. The shell material was divided into eight analytical samples of $2 \mathrm{~g}$ weight, powdered in an agate mortar, and prepared for the XRD studies at the XRD laboratory of the Tallinn University of Technology. Different samples were heat-treated at temperatures of 200, 300, 400, 500, 600, 700, 900, and $1000{ }^{\circ} \mathrm{C}$. After each thermal treatment an XRD pattern was obtained in a step-scan mode, using the X-ray diffractometer HZG-4 in the $2 \Theta$ range from $49.9^{\circ}$ to $54.0^{\circ}$ of Cu-radiation $\left(\lambda \mathrm{K}_{\alpha 1}=1.540510 \AA\right.$, step $0.01^{\circ}$, measuring time for each point $\left.25 \mathrm{~s}\right)$. This high-angle interval has proven to be useful for distinguishing between apatite varieties with different lattice parameters. The measured angular range contains apatite reflections $321,410,402$, and $004 ; 112$ reflection of quartz was used for the correction of the instrumental shift. Background subtraction was made using the formula 


$$
I_{\mathrm{bg}}=A+B \cdot \sin ^{-1}(2 \theta),
$$

where $I_{\mathrm{bg}}$ is the intensity of the background, $A, B$ are background parameters.

A whole-pattern fitting procedure was applied to the measured XRD pattern, with modified Lorenzian function profile-shape, generated by the formula

$$
I(x)=I(0)\left[\frac{w^{2}}{w^{2}+x^{2}}\right]^{2} .
$$

In a refinement model, each reflection was calculated as a sum of $\mathrm{K}_{\alpha 1}$ and $\mathrm{K}_{\alpha 2}$, where $K_{\alpha 1}=2 K_{\alpha 2}$ (Kallaste 1990). The following parameters were varied: number of apatite phases (1 or 2), lattice parameters (i.e. positions of reflections), half-widths (parameter $w$ ) and linear intensities. The quality of refinement was estimated using the character of noise (error curve), which itself is a difference between the measured and calculated intensities at point $x$. All calculations were carried out in reciprocal lattice. An application of the used model is presented in Fig. 2.

The fluorine content of an unheated sample was determined by the wet-chemical method by Dr. K. Tõnsuaadu at the Institute of Basic and Applied Chemistry, Tallinn University of Technology.

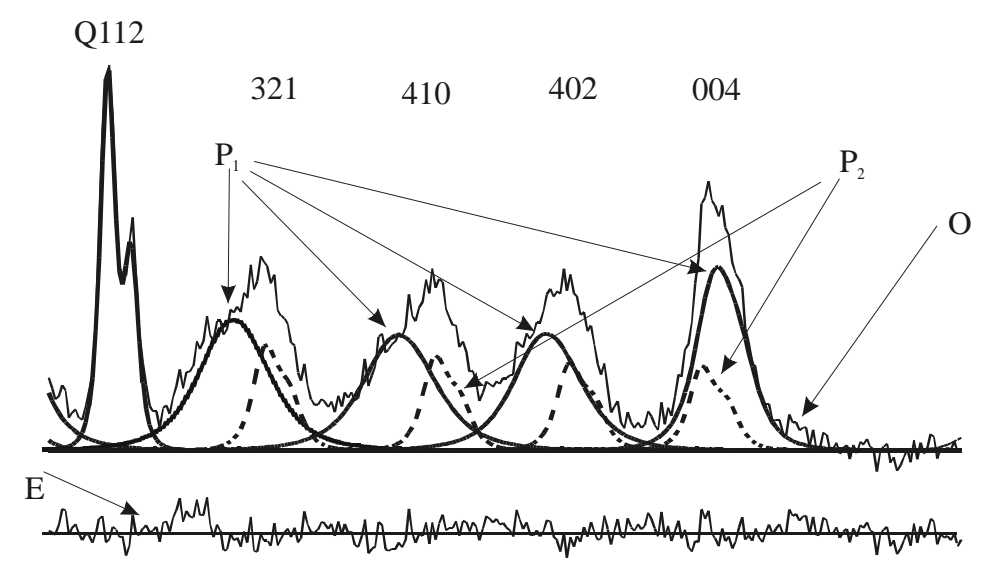

Fig. 2. An example of the calculation model for shell apatite of Obolus apollinis. The measured XRD pattern $(\mathrm{O})$, fitting functions for both apatite phases $\left(\mathrm{P}_{1}\right.$ and $\mathrm{P}_{2}$, dotted line), and error curve (E) are shown. Apatite XRD reflections are marked by their indices. The quartz 112 reflection is indicated by $\mathrm{Q}$. 


\section{RESULTS AND DISCUSSION}

As revealed by the XRD analysis, all the studied samples consist of apatite; no other phosphatic minerals were detected. According to the wet-chemical analysis, the fluorine content of an unheated sample was $1.62 \mathrm{wt} \%$. Crystallinity and lattice parameters were found to be in strong correlation with the heating temperature. In moderately heated samples $\left(200\right.$ to $700{ }^{\circ} \mathrm{C}$ ), two distinct apatite varieties were found. The calculated lattice parameters are presented in Table 1 . The selected XRD patterns and the change of lattice parameters as a function of heating temperature are shown in Figs. 3 and 4, respectively.

The used whole-pattern fitting method enabled us to distinguish between two distinct apatite varieties in cases of an obvious asymmetric shape of XRD patterns. The distinction between these varieties is possible at temperatures up to $700{ }^{\circ} \mathrm{C}$. At higher temperatures, this distinction disappears, due to thermal changes in crystallinity and chemical composition of apatite. Thus, the lattice parameters for temperatures 900 and $1000{ }^{\circ} \mathrm{C}$ in Table 1 represent the average composition of the heated apatite samples.

The values of lattice parameters of the detected apatite phases give indirect information on their chemical composition. Phase 1, with lattice parameter $a$ higher than $9.37 \AA$, should belong to the $\mathrm{OH}$ - (or Cl-) carbonate apatite series, while the values of $a$ for Phase 2 are characteristic of F-carbonate-apatites (McConnell 1973) of B-type (sensu Elliott 1994). Chlorine in the lattice of biogenic apatites is mostly associated with vertebrate tooth enamel (Michel et al. 1995) and, possibly, with specific diagenetic alteration conditions, but it is not usual in Recent or fossil lingulate brachiopod shells. Chlorine has not been detected in chemical analyses

Table 1. Lattice parameters of two apatite phases from the heated valves of the Upper Cambrian lingulate brachiopod Obolus apollinis Eichwald from the Tosna Formation, Lava section

\begin{tabular}{|c|c|c|c|c|}
\hline \multirow{3}{*}{$\begin{array}{c}\text { Temperature, } \\
{ }^{\circ} \mathrm{C}\end{array}$} & \multicolumn{4}{|c|}{ Apatite lattice parameter, $\AA$} \\
\hline & \multicolumn{2}{|c|}{ Phase 2} & \multicolumn{2}{|c|}{ Phase 1} \\
\hline & $a_{1}$ & $c_{1}$ & $a_{2}$ & $c_{2}$ \\
\hline 200 & 9.349 & 6.895 & 9.382 & 6.884 \\
\hline 300 & 9.345 & 6.895 & 9.376 & 6.879 \\
\hline 400 & 9.345 & 6.893 & 9.376 & 6.877 \\
\hline 500 & 9.346 & 6.895 & 9.373 & 6.879 \\
\hline 600 & 9.348 & 6.899 & 9.380 & 6.885 \\
\hline 700 & 9.347 & 6.900 & 9.374 & 6.888 \\
\hline 900 & - & - & 9.374 & 6.893 \\
\hline 1000 & - & - & 9.375 & 6.892 \\
\hline
\end{tabular}




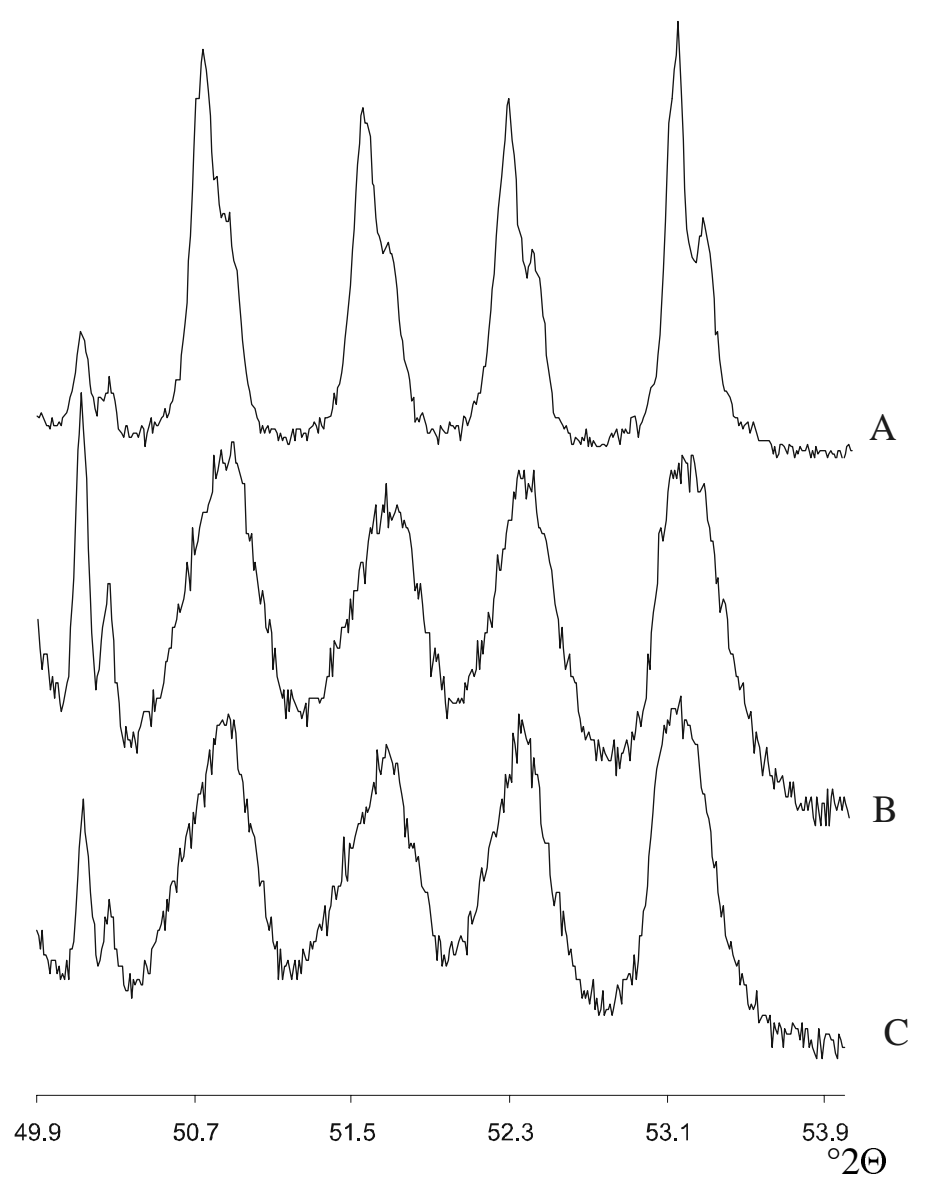

Fig. 3. The XRD patterns of shell apatite of Obolus apollinis from the Lava section, Tosna Formation. A, heated up to $1000{ }^{\circ} \mathrm{C}$; B, heated up to $500{ }^{\circ} \mathrm{C}$; C, natural.
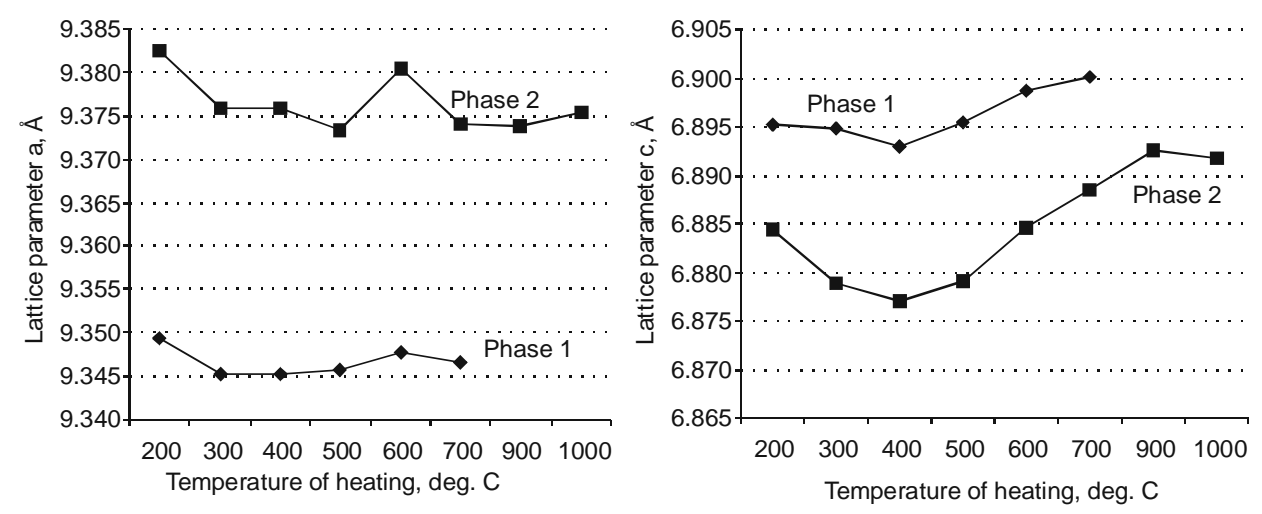

Fig. 4. Lattice parameters of the two detected apatite phases in the valves of Obolus apollinis from the Tosna Formation, Lava section, as a function of heating temperature. 
of shells from the Obolus-phosphorite (e.g. Raudsep 1987, 1997; Heinsalu et al. 1979; Zanin et al. 1979). In stoichiometric formulas, based on XRD and chemical analysis, it has been reported that a little amount of hydroxyl ion is present in the lingulate brachiopod shells from Obolus-phosphorites (e.g. Ushatinskaya et al. 1988).

The presence of hydroxylapatite in Recent vertebrate bones and teeth has long been regarded as a common knowledge. It appears that recent NMR solid-state spectroscopy studies have removed the doubts related to previous difficulties with detecting $\mathrm{OH}^{-}$in the structure of skeletal apatites (Cho et al. 2003). Evidence from XRD studies and chemical analyses has supported the presence of hydroxyl ion in Recent lingulate brachiopod shells, where it has lattice parameter intervals $a=9.38-9.40 \AA$ and $c=6.86-6.88 \AA$ (Puura \& Nemliher 2001).

Empirical studies of synthetic F-carbonate-apatites have suggested negative linear correlation between lattice parameter $a$ and $\mathrm{CO}_{3}$ content (Schuffert et al. 1990). It is also known that lattice parameter $a$ and OH content are positively correlated, although carbonate substitutions to different positions in the apatite lattice may somewhat obscure this general trend (Elliott 1994). Thus, lattice parameters can be used for characterizing multiple phases in a continuum of apatite varieties and used for indirect and approximate evaluation of the chemical composition, especially when combined with other analytical data.

Based on the above background knowledge, we interpret the lattice parameters of Phase 1 as indicating the presence of $\mathrm{OH}$ ions in the apatite lattice. This interpretation is supported by a relatively low $\mathrm{F}$ content (1.62 wt $\%)$, as compared to that of pure F-apatite $\mathrm{Ca}_{10}\left(\mathrm{PO}_{4}\right)_{6} \mathrm{~F}_{2}(3.77 \mathrm{wt} \%)$. However, studies on synthetic carbonate-containing OH-apatite of type A (Ivanova et al. 2001) have shown that the carbonate position in the apatite lattice may strongly affect lattice parameter values of non-heated and heat-treated samples.

The lattice parameters of the two detected apatite phases in the heat-treated samples show nonlinear changes (Fig. 4). According to Bliskovskij (1983), the main transformation of $\mathrm{OH}$-apatite into oxyhydroxyapatite starts at a temperature over $1200{ }^{\circ} \mathrm{C}$, but a later study (Liao et al. 1999) has shown that this process takes place in the temperature range $1000-1360^{\circ} \mathrm{C}$. Both studies confirm that the main changes in the structure of $\mathrm{OH}$-apatite take place during the cooling at a temperature higher than $1000{ }^{\circ} \mathrm{C}$.

The lattice parameters of Phase 1 are close to those of the apatite in Recent lingulate brachiopod shells (Puura \& Nemliher 2001), whilst Phase 2 has lattice parameters close to the apatite in phosphatic pebbles from the Obolus Sandstone of Estonia (Kallavere Formation) of about the same age (Nemliher \& Puura 1996b). Thus, we interpret the two phases of apatite as OH-containing primary shell material that may be slightly altered diagenetically (Phase 1) and secondary, recrystallized and precipitated carbonate-fluorapatite (Phase 2).

As regards the distribution of the two main phases of apatite within the shell, the shell structure offers some clues. Obolus apollinis has baculate shell structure, 
similar to Recent Glottidia and discinids (Williams \& Cusack 1999). In the crosssection of fossil shells, it can be observed as rhythmic alternation of compact laminae and laminae of apatitic rods (baculi). From the SEM photos (Fig. 5; see also Williams \& Cusack 1999, fig. 6a-d) it is evident that compact laminae have preserved rather well during the fossilization of the shell. In contrast, the space between the compact laminae is filled with structureless substance. Within this matrix of precipitated apatite, apatitic rods (baculi) can be observed (Popov \& Holmer 2003, fig. 6E,F). Baculi can be regarded as original structures (our preferred interpretation) or as pseudomorphs formed during the earliest stages of fossilization (e.g. Williams \& Cusack 1999, p. 235).

Hydroxylapatites are usually thermodynamically unstable outside living organisms and tend to be replaced by F-containing carbonate apatites. Thus the post-mortem processes include skeletal apatite recrystallization or dissolution. Usually, carbonate fluorapatites are formed and hydroxylapatites are not preserved. We conclude that the studied shells of Obolus apollinis may represent a rare case, where part of carbonate hydroxylapatite may be conserved within compact laminae, preserved in near-equilibrium conditions since the subfossil state. In contrast, the organic and possibly some phosphatic structures between the compact laminae have recrystallized and formed carbonate F-apatite with a high carbonate content. As the original and/or recrystallized pseudomorphic structures have preserved without further dissolution, it can be expected that the fossilization has been a rapid, almost instant process.
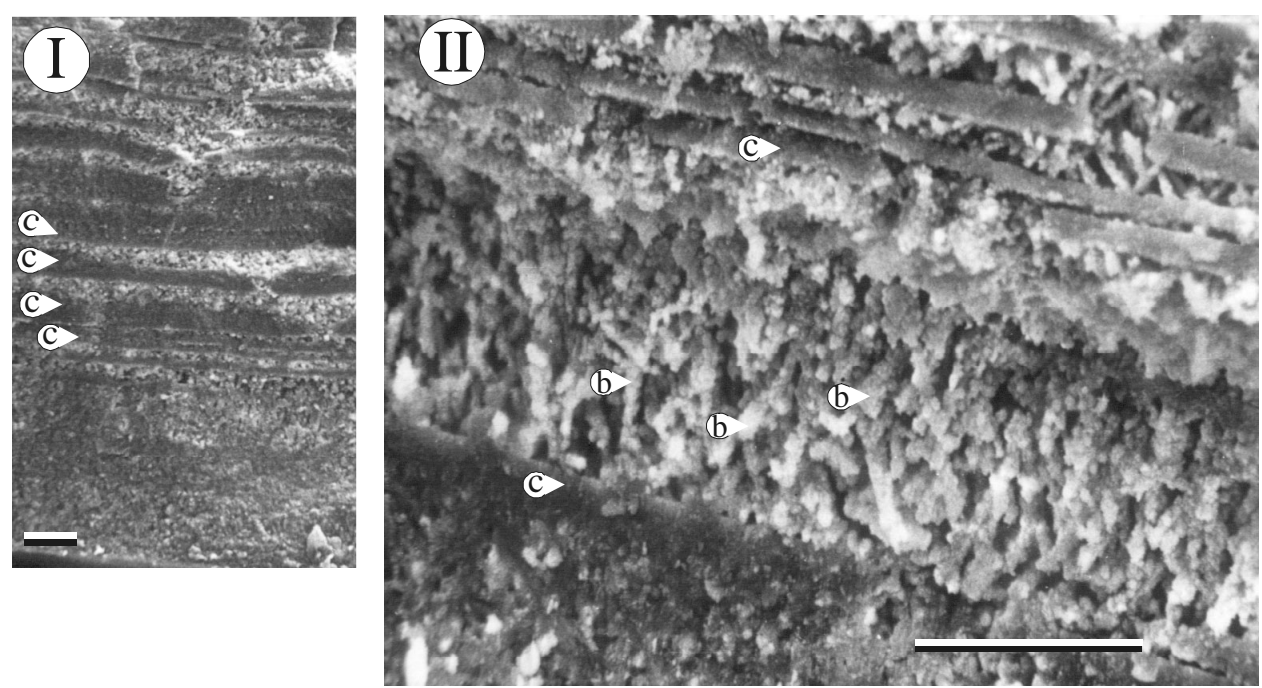

Fig. 5. Fractured cross-section of Obolus apollinis treated by $5 \% \mathrm{H}_{2} \mathrm{O}_{2}$. Upper Cambrian, Tosna Formation, Lava section. c, compact laminae; b, baculi. Scale bars: I - $100 \mu \mathrm{m}$ and II $-20 \mu \mathrm{m}$. 


\section{CONCLUSIONS}

From the XRD studies of a series of analytical samples from one rock sample heated to $200-1000{ }^{\circ} \mathrm{C}$, we conclude that the studied valves of the Cambrian lingulate brachiopod Obolus apollinis Eichwald contain two distinct apatite varieties: an $\mathrm{OH}$-containing F-carbonate apatite (Phase 1), close to the apatite of Recent or subfossil lingulate shells, and an F-carbonate apatite (Phase 2), a product of the recrystallization of original apatite and precipitation of new apatite to the free space available after the disintegration of organic tissues of the shell.

To our knowledge, the preservation of the F-containing carbonate hydroxylapatite phase in fossils as old as almost 500 million years has previously not been documented. We expect that this possibility of long-time preservation has implications for the studies in the fields of biomineralization, taphonomy, and geochemistry, where the question of preservation of primary signatures is crucial.

\section{ACKNOWLEDGEMENTS}

This work was supported by the Estonian Science Foundation (grant No. 5275) and is a contribution to IGCP Project No. 503 "Early Palaeozoic Palaeogeography and Palaeoclimate". We appreciate the valuable comments and suggestions from the reviewers, Dr. Linda Hints (Tallinn) and Prof. Lars. E. Holmer (Uppsala).

\section{REFERENCES}

Bliskovskij, V. Z. 1983. Veshchestvennyj sostav i obogatimost' fosforitovykh rud. Nedra, Moscow (in Russian).

Cho, G., Yaotang, W. \& Ackerman, J. L. 2003. Detection of hydroxyl ions in bone mineral by solidstate NMR spectroscopy. Science, 300 (5622), 1123-1127.

Elliott, J. C. 1994. Structure and chemistry of apatites and other calcium orthophosphates. Studies in Inorganic Chemistry, 18. Elsevier, Amsterdam.

Heinsalu, H. N., Gorbunova, L. I. \& Viiding, H. A. 1979. The mineral composition of Estonian shelly phosphorites. In Veshchestvennyi sostav fosforitov (Zanin, Ju. N., ed.), pp. 119-126. Nauka, Novosibirsk (in Russian).

Holmer, L. \& Popov, L. 2000. Lingulata. In Treatise on Invertebrate Paleontology, Part H. Brachiopoda. Revised. Volume 2: Linguliformea, Craniiformea and Rhynchonelliformea (part) (Kaesler, R. L., ed.), pp. 30-146. Geological Society of America, Boulder and University of Kansas, Lawrence.

Ivanova, T. I., Frank-Kamenetskaya, O. V., Kol'tsov, A. B. \& Ugolkov, V. L. 2001. Crystal structure of calcium-deficient carbonated hydroxyapatite. Thermal decomposition. J. Solid State Chem., 160, 340-349.

Kallaste, T. 1990. Structural indicators of the origin of Estonian Vendian-Lower Palaeozoic sedimentary iron sulphides. Proc. Estonian Acad. Sci. Geol., 39, 50-59 (in Russian). 
Krasilinkova, N. A. \& Ilyin, A. V. 1989. The Ordovician Baltic phosphorite basin, USSR. In Phosphate Deposits of the World. Volume 2. Phosphate Rock Resources (Notholt, A. J. G, Sheldon, R. P. \& Davidson, D. F., eds.), pp. 494-496. Cambridge University Press, Cambridge.

Liao, C.-J., Lin, F.-H., Chen, K.-S. \& Sun, J.-S. 1999. Thermal decomposition and reconstitution of hydroxyapatite in air atmosphere. Biomaterials, 20, 1807-1813.

McConnell, D. 1973. Apatite, Its Crystal Chemistry, Mineralogy, Utilization and Geologic and Biologic Occurrences. Springer, New York.

Michel, V., Ildefonse, P. \& Morin, G. 1995. Chemical and structural changes in Cervus elaphus tooth enamels during fossilization (Lazaret cave): a combined IR and XRD Rietveld analysis. Appl. Geochem., 10, 145-159.

Nemliher, J. \& Kallaste, T. 2002. Secondary alteration of the shell apatite of Discinisca tenuis from Lüderitz, Namibia. Lithol. Miner. Resour., 37, 18-24.

Nemliher, J. \& Puura, I. 1996a. Shell mineralogy of the lingulate brachiopods from the Baltic "Obolus phosphorite". In Working Group on Ordovician Geology of Baltoscandia (Stouge, S., ed.). Report Series, Geol. Surv. Denmark and Greenland, 98, 79-89.

Nemliher, J. \& Puura, I. 1996b. Upper Cambrian basal conglomerate of the Kallavere Formation on the Pakri Peninsula, NW Estonia. Proc. Estonian Acad. Sci. Geol., 45, 1-8.

Öpik, A. 1929. Der Estländische Obolenphosphorit. Im Verlage des estländischen Handels- und Gewerbeministeriums, Tallinn.

Popov, L. E. \& Holmer, L. E., 2003. Understanding linguloid brachiopods: Obolus and Ungula as examples. Carnets Géol. / Notebooks Geol., Article 2003/06, 1-13.

Popov, L. Ye., Khazanovitsh, K. K., Borovko, N. G., Sergeyeva, S. P. \& Sobolevskaya, P. F. 1989. Key Sections and Stratigraphy of the Phosphate-Bearing Obolus Beds of the North-East Part of Russian Platform. Nauka, Leningrad (in Russian).

Puura, I. 1996. Lingulate Brachiopods and Biostratigraphy of the Cambrian-Ordovician Boundary Beds in Baltoscandia. Doctoral thesis presented to the Department of Historical Geology \& Palaeontology, Institute of Earth Sciences, Uppsala University. Uppsala.

Puura, I. \& Nemliher, J. 2001. Apatite varieties in Recent and fossil linguloid brachiopod shells. In Brachiopods Past and Present (Brunton, C. H. C., Cocks, L. R. M. \& Long, S. L, eds.). Systematics Assoc. Spec. Vol. Ser., 63, 7-16.

Puura, I. \& Viira, V. 1999. Chronostratigraphy of the Cambrian-Ordovician boundary beds in Baltoscandia. Acta Univ. Carolinae Geol., 43, 5-8.

Raudsep, R. 1987. Shelly (Obolus-) phosphorite. In Geology and Mineral Resources of the Rakvere Phosphorite-Bearing Area (Puura, V., ed.), pp. 128-142. Valgus, Tallinn (in Russian).

Raudsep, R. 1997. Phosphorite. In Geology and Mineral Resources of Estonia (Raukas, A. \& Teedumäe, A., eds.), pp. 331-336. Estonian Academy Publishers, Tallinn.

Schuffert, J. D., Kastner, M., Emanuele, G. \& Jahnke, R. A. 1990. Carbonate-ion substitution in francolite: a new equation. Geochim. Cosmochim. Acta, 54, 2323-2328.

Ushatinskaya, G. T., Zezina, O. N., Popov, L. Ye. \& Putivtseva, N. V. 1988. On the microstructure and composition of the brachiopods with calcium phosphate shell. Rep. Acad. Sci. USSR, 300, 700-703 (in Russian).

Williams, A. \& Cusack, M. 1999. Evolution of a rhythmic lamination in the organophosphatic shells of brachiopods. J. Struct. Biol., 126, 227-240.

Zanin, Yu. N., Krivoputskaya, L. M., Vahrameev, A. M., Gusev, G. M., Lemina, N. M., Lundin, A. G., Lobov, A. G., Rjahov, A. P. \& Jusupov, G. S. 1979. The changes of composition and structure of calcium phosphates in the processes of katagenesis and weathering and the influence of changes on the solubility. In Veshchestvennyi sostav fosforitov (Zanin, Ju. N., ed.), pp. 37-45. Nauka, Novosibirsk (in Russian). 


\title{
Apatiidi erimid Kambriumi brahhiopoodi Obolus apollinis Eichwald kojas
}

\author{
Jüri Nemliher, Tiia Kurvits, Toivo Kallaste ja Ivar Puura \\ Uuriti fosfaatse kojaga Kambriumi käsijalgse Obolus apollinis Eichwald \\ kodade apatiidi koostist. Materjal pärines Ingerimaalt (Leningradi oblast) Laava \\ jõe paljandist Tosna kihistu basaalkihtidest, mis on Ülem-Kambriumi (Furongi) \\ vanusega. Kuumutatud kodade röntgenstruktuuranalüüsil selgus, et 200-700 \\ kraadi juures eristub kaks apatiidi faasi, temperatuuril 900-1000 kraadi aga üks \\ faas. Võreparameetrite põhjal järeldati, et üks faas võib tõenäoliselt esindada \\ karbonaat-hüdroksüülapatiiti, mille säilimine nii vanades kodades on erakordne. \\ Teise faasi, karbonaat-fluorapatiidi teke seostub nii primaarse karbiapatiidi üles- \\ lahustumise ja rekristalliseerumisega kui ka uue apatiidi väljasettimisega koja \\ sisemuses tekkivasse ruumi, mis vabaneb orgaaniliste kudede lagunemisel.
}

